\title{
Assesment Work Fatigue To Workers In Environment Underground Mining Areas Based On Fatigue Assesment Scale Questionnaires
}

\author{
Siti Rachmawati $^{1 *}$, Miftaqul Aktsari ${ }^{2}$, Anis Suryaningsih ${ }^{3}$, Hashfi Hawali Abdul Matin ${ }^{1}$, \\ Iwan Suryadi ${ }^{2}$ \\ ${ }^{1}$ Program of Environmental Science, Sebelas Maret University, Surakarta- Indonesia \\ ${ }^{2}$ Program of Hygiene and Occupational Health and Safety, Sebelas Maret University, Surakarta- \\ Indonesia \\ ${ }^{3}$ Program of Pancasila and Citizenship Education, Sebelas Maret University, Surakarta- Indonesia
}

\begin{abstract}
Fatigue is recognized as a high potential risk for accidents and therefore an assessment of work fatigue is required. The purpose of this study is to describe the overall work fatigue assessment and based on work fatigue factors using questionnaires for the fatigue rating scale for workers in underground mining areas. This study used a descriptive method to describe the overall assessment of work fatigue and assessment of work fatigue based on factors related to fatigue using questionnaire scale fatigue assessment of workers in underground mining areas at PT. Y. Overall fatigue assessment based on fatigue evaluation questionnaire results obtained $54.55 \%$ of workers who experience fatigue. Fatigue assessment based on factors related to work fatigue shows that workers who tend to experience fatigue are $>45$ years of age, $<7$ hours of sleep, $>5$ years of work, 12 hours of work, supervisor type II / jumbo operator drill, jumbo drill operator, LHD operator, and service crew / helper jumbo drill, work climate $>\mathrm{NAB}(>29.00 \mathrm{C})$ and noise $>\mathrm{NAB}(>85 \mathrm{~dB}$ A). Underground mining workers tend to experience fatigue. The older the worker's age, the less sleep time, the longer the work period, the longer work time, the heavier the type of work, the hotter the working climate and the noisier it tends to experience fatigue.
\end{abstract}

Keywords. Work Fatigue; Underground Mine.

\footnotetext{
* Corresponding author: siti.rachmawati@staff.uns.ac.id
} 


\section{Introduction}

The International Labor Organization (ILO) stated that workplace accidents caused by fatigue are increasing. Every year there are work accidents due to fatigue as many as two million workers [11]. The Director General of Labor Inspection Development said that in Indonesia every day an average of 414 occupational accidents and $27.8 \%$ were caused by fatigue. Work fatigue is proven to contribute more than $60 \%$ in workplace accidents [3].

The World Health Organization (WHO) in the health model created until 2020 predicted a psychological disorder in the form of a feeling of severe fatigue and which led to depression would become the number two killer disease after heart disease. The results of a study conducted by the Japanese Ministry of Manpower of 12,000 companies involving around 16,000 workers in the country randomly selected showed that $65 \%$ of workers complained of physical fatigue due to routine work, $28 \%$ complained of mental fatigue and around $7 \%$ of workers complained of severe stress and feel excluded [12].

Fatigue is a common complaint in the general public and in the working population. In workers, about $20 \%$ have symptoms of work fatigue. Work fatigue can be characterized by decreased work performance or all conditions that affect all organism processes, including several factors such as feelings of fatigue (subjective feeling of fatigue), decreased motivation, and decreased mental and physical activity [6].

This research was conducted on underground mining workers, because based on Antam data in 2011-2018, the highest accident occurred at the factory site and underground mining as many as 79 cases where 43 cases were mild categories, 28 cases were severe cases and 8 cases were fatal / dead cases. The working time chosen in this study is shift 1 (08.00 am $20.00 \mathrm{pm}$ ) because based on the analysis of PT Y's accident statistics in 2018 it was stated that many accidents occurred in shift 1 where $42 \%$ of accidents occurred at $06.00-12.00$ and $36 \%$ of accidents occurred at $12.00-18.00$.

PT Y has conducted a fatigue assessment in 2018 using a reaction timer and a questionnaire measuring the feeling of work fatigue (KAUPK2). The results of the fatigue assessment conducted by PT Y states that on average workers experience moderate fatigue and some experience mild fatigue. But in reality, when an observation is made directly, the measurement results are not in accordance with what is happening in the field. So the authors conducted fatigue assessment using other methods, namely fatigue assessment scale questionnaire.

\section{Research methods}

This research used descriptive method. Descriptive method is carried out to determine the existence of an independent variable, either only on one or more variables (independent variables or independent variables) without making a comparison of the variables themselves and looking for relationships with the other variables [8]. The sampling technique in this study was done by cluster random sampling, where the sample taken was done by selecting a cluster / area randomly, without regard to strata in the population as representatives of the population, then all elements in the selected cluster were used as research samples [7]. The study was conducted at PT Y. The total population of the study was 50 workers and the study sample were 22 workers. Work fatigue assessment used the fatigue assessment scale questionnaire. 


\section{Result}

Work Fatigue Assessment

Table 1. Work Fatigue Assessment Results Based on Fatigue Assessment Scale Questionnaire

\begin{tabular}{|c|c|c|}
\hline $\begin{array}{c}\text { Fatigue } \\
\text { Classification }\end{array}$ & Data (n) & Percentage (\%) \\
\hline Low fatigue & 10 & 45,45 \\
\hline High fatigue & 12 & 54,55 \\
\hline Total & 22 & 100 \\
\hline
\end{tabular}

Based on Table 1 showed the results of the overall work fatigue assessment subjectively based on the fatigue evaluation scale questionnaire on the underground mining area mine which states that from a total of 22 respondents, as many as 10 people $(45.45 \%)$ experienced low fatigue and 12 people (54\%) experienced high fatigue.

Table 2. Assessment of Work Fatigue Based on Factors Related to Fatigue Using Fatigue Assessment Scale Questionnaire

\begin{tabular}{|c|c|c|c|c|}
\hline No & Variable & Category & $\begin{array}{c}\text { Fatigue } \\
\text { Classification }\end{array}$ & (n) \\
\hline \multirow{4}{*}{1} & \multirow{4}{*}{ Age } & \multirow{2}{*}{$<45$ years } & Low fatigue & 7 \\
\hline & & & High fatigue & 6 \\
\hline & & \multirow[b]{2}{*}{$>45$ years } & Low fatigue & 3 \\
\hline & & & High fatigue & 6 \\
\hline \multirow{4}{*}{2} & \multirow{4}{*}{$\begin{array}{l}\text { Sleep } \\
\text { Time }\end{array}$} & \multirow{2}{*}{$<7$ hours } & Low fatigue & 4 \\
\hline & & & High fatigue & 11 \\
\hline & & \multirow{2}{*}{$>7$ hours } & Low fatigue & 6 \\
\hline & & & High fatigue & 1 \\
\hline \multirow{4}{*}{3} & \multirow{4}{*}{$\begin{array}{l}\text { Work } \\
\text { Period }\end{array}$} & \multirow{2}{*}{$\leq 5$ years } & Low fatigue & 2 \\
\hline & & & High fatigue & 0 \\
\hline & & \multirow[b]{2}{*}{$\geq 5$ years } & Low fatigue & 8 \\
\hline & & & High fatigue & 12 \\
\hline \multirow{2}{*}{4} & \multirow{2}{*}{$\begin{array}{l}\text { Length of } \\
\text { working }\end{array}$} & \multirow{2}{*}{$\begin{array}{l}\leq 8 \text { hours (non } \\
\text { shift) }\end{array}$} & Low fatigue & 2 \\
\hline & & & High fatigue & 1 \\
\hline
\end{tabular}




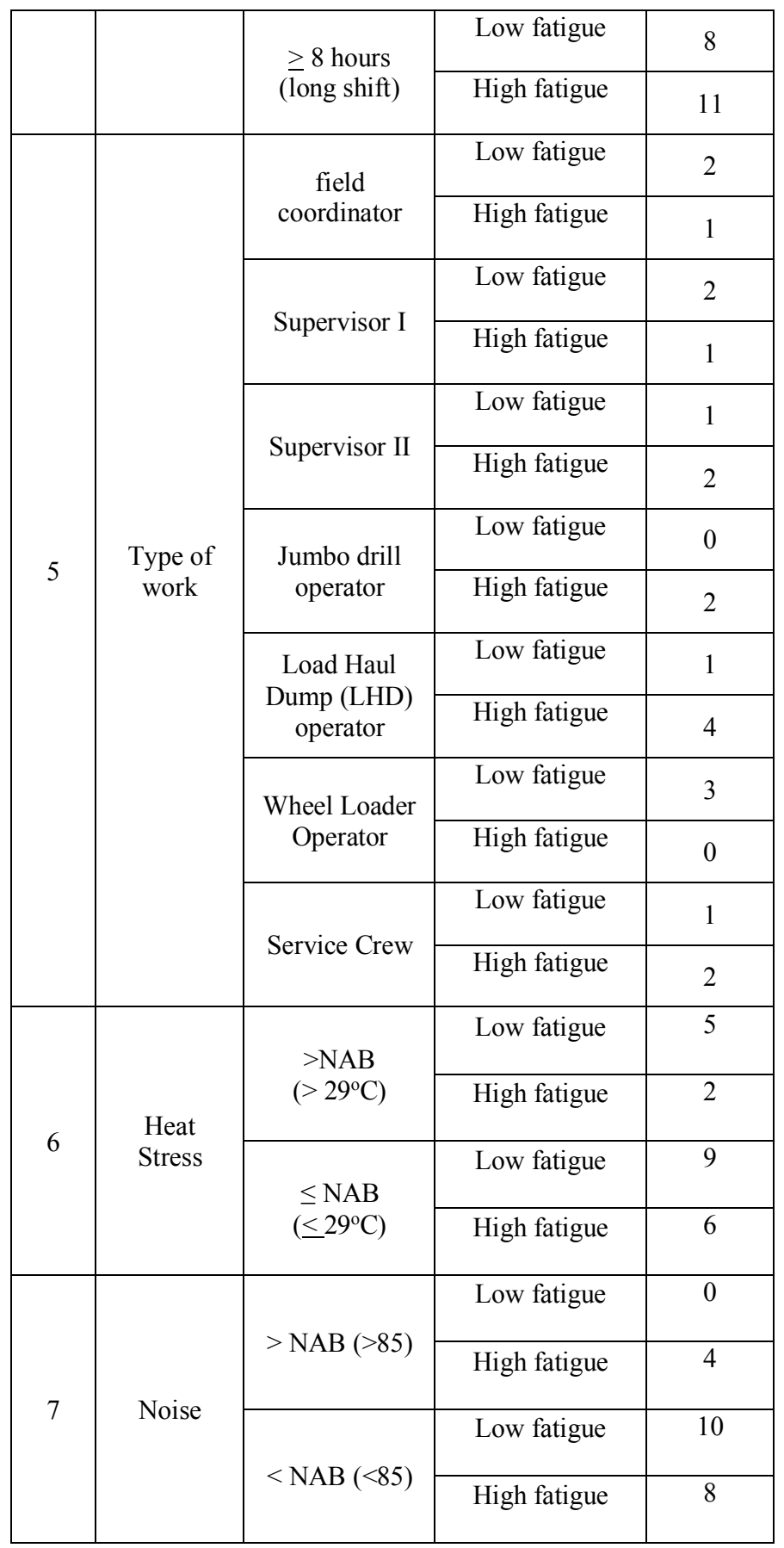

\section{Discussion}

Overall Work Fatigue Assessment Based on Fatigue Assessment Scale Questionnaire A. Individual Factors 
1. Age

Work fatigue assessment based on age factor using the fatigue rating scale questionnaire for underground mining workers, it is known that respondents with age $\leq 45$ years amounted to 13 people and respondents with age $>45$ years amounted to 9 people.

The results stated that the percentage of respondents age $>45$ years who experienced low fatigue was smaller at $33.33 \%$ ( 3 out of 9 people) than respondents with age $\leq 45$ years where the percentage who experienced low fatigue was greater namely $53.85 \%$ ( 7 out of 13 people). The percentage of respondents age $>45$ years who experienced high fatigue was greater namely $66.67 \%$ (6 of 9 people) than respondents with age $\leq 45$ years where the percentage who experienced high fatigue was smaller namely $46.15 \%$ ( 6 out of 13 people).

The results of this research are consistent with atiqoh the theory that the older the more easily experience fatigue due to decreased organ function [1]. The results of this research are also in accordance with [10] which states that work capacity will decrease towards the age of 45 years and over. The results of this research are also in line with research conducted by [18] and [2], their research mentioned that respondents under the age of 45 were less likely to experience fatigue, whereas respondents aged over 45 years experienced more fatigue and also respondents with age above 45 years are more easily experienced fatigue compared to workers under the age of 45 .

Based on the results of interviews conducted with respondents, for respondents who have exceeded 45 years but must be more than respondents who use additional vitamins both herbal to improve stamina and perform activities that can relax the respondent's body. For respondents under the age of 45 years the higher of respondents could not take advantage of vacation time and rest periods there also did not require additional vitamins.

2. Sex

Gender is indeed one of the factors related to fatigue as the theory mentioned earlier that women tend to be more tired than men [4]. However, because underground mining workers including mine $\mathrm{B}$ are only male so the sex factor is not further investigated in the research conducted.

3. Sleeping time

The results of this research stated that respondents with less than 7 hours of sleep experience more fatigue compared with respondents who have enough sleep time that is $\geq 7$ hours. The results of this research are in line with research conducted by [13] which states that the higher the sleep duration, the lower the work fatigue that occurs.

Based on the results of interviews conducted with respondents, for respondents who had more than 7 hours of sleep but experienced high fatigue because respondents could not maximize the time off given by the company well to rest because there were other activities carried out with the family and also the respondent had never taking additional vitamins. For responses that have less than 7 hours of sleep but have low fatigue because respondents have a way to maintain their stamina by exercising regularly and taking additional vitamins both drugs and herbs.

B. Work Factor

1. Work period

The results of this study indicate that respondents who have a work period of $>5$ years (long) tend to experience more fatigue compared to respondents whose work 
period is $\leq 5$ years (new). The results of this study are in accordance with the theory which states that the longer the work period, the longer the higher, because the longer work can lead to increased feelings of boredom due to monotonous work increase the level of importance generated [3].

Based on the results of interviewed conducted with respondents, for respondents with a long work period of more than 5 years but experiencing low fatigue because respondents had a way to overcome the boredom and fatigue that exist by doing recreation or doing hobbies / pleasures of the respondent for example listening to music and traveling. In addition, respondents also use the available vacation time to maximize rest in returning stamina to work the next day.

2. Length of working

The percentage of respondents with a long work time of 8 hours (non-shift workers) who experienced low fatigue was greater at $66.67 \%$ ( 2 of 3 people) than respondents with long work hours of 12 hours (long shift workers) where the percentage who experienced low fatigue was smaller at $42,11 \%$ ( 8 out of 19 people). The percentage of respondents with 8 hours work time (non-shift workers) who experienced high fatigue was smaller at $33.33 \%$ ( 1 of 3 people) than respondents with 12 hours work time (long shift workers) where the percentage who experienced high fatigue was greater namely $57,89 \%$ (11 out of 19 people).

The results of this research indicate that respondents worked for 12 hours (long shifts) compared to respondents who worked for 8 hours (without shifts). The results of this research are in accordance with a theory that discusses the length of work done later on this person will increase and continue to accumulate over time, so as to increase higher efficiency [5]. This is also in accordance with the theory which states that 12-hour / day work shifts can change the biological rhythm due to irregular rest periods so that it can have an effect on causing improvements [14].

Based on the results of interviewed, respondents with 8 hours of work (non-shift) have not increased which requires improvement of 45 years and also work periods that have ( $>5$ years). For respondents with 12 hours long work (long shift) but it is necessary to consider lower ones according to the old respondents still have better stamina, have long working periods or under 5 years, thus increasing those that have piled up like other respondents, besides that also involving respondents taking additional vitamins.

3. Type of Work

The results of this research stated that respondents with the type of work as field coordinators, supervisor I and wheel loader operators tend to experience low fatigue compared to respondents with type of work as supervisor II who also doubles as a jumbo drill operator, jumbo drill operator, LHD operator and service crew. The results of this research are in accordance with the theory by [2] which states that the level of worker's ability can be measured through a person's workload both physical and mental workload. The results of this research are also related to the theory from [9] which states that a job called heavy is characterized by a large expenditure of physical energy and mental abilities.

According to the authors based on direct observations to the field and also from interviews with respondents, for the type of work the field coordinator, supervisor I, and wheel loader operators tend to experience low fatigue because the workload given in the mine is not so draining especially physical compared to other workers such as Supervisor II who concurrently worked as a jumbo drill operator, jumbo drill operator, LHD operator and service crew. However, for the coordinator and supervisor I have complaints related to fatigue in psychic sometimes due to their 
greater task related responsibilities in the work that exert more thought. Respondents who experience low fatigue even though the workload received is heavy because the respondents have a work period of $>5$ years so that respondents are accustomed to undergoing work activities.

4. Monotomi

Based on direct observations made, the work activities carried out are the same every day and in the same area, with the same environment. So that the activities carried out by all respondents are monotonous. Because all the work carried out is clearly monotonous and there are no other comparison variables, the monotony factor is not further investigated in the research conducted.

C. Work Environment Factors

1. Heat Pressure / Working Climate

Respondents with a work climate exceeding the NAB $\left(>29^{\circ} \mathrm{C}\right)$ experienced more fatigue compared to respondents who were in a work climate below the NAB $(\leq 29$ ${ }^{0} \mathrm{C}$ ). The results of this research are in line with research conducted by [15] which states that the hotter the working climate, the higher the level of fatigue.

Based on the results of interviewed conducted with respondents, many respondents complained that a hot and hot work environment often increased respondents' fatigue during work. In addition, from the results of interviews conducted it can be seen that respondents with a work climate below the NAB ( $\leq$ $29^{\circ} \mathrm{C}$ ) but experience high fatigue due to the age factor of respondents who are old ( $>45$ years) also have less than maximum sleep and rest periods.

2. Noise

Respondents with noise exceeding NAB $(>85 \mathrm{dBA})$ experienced more fatigue than respondents with noise below NAB $(\leq 85 \mathrm{dBA})$. The results of this research are in accordance with the results of [16] study which states that the higher the noise intensity, the more severe and higher the level of work fatigue in the workforce. Based on the results of interviews conducted with respondents it can be seen that respondents with noise below the $\mathrm{NAB}(\leq 85 \mathrm{~dB}$ A) but experience high fatigue, because there are still found respondents who do not used PPE, which should used 2 PPE ear plugs and ear muffs, but there are still who only used ear plugs or ear muffs. In addition, there are also other factors such as the age factor of respondents who are old ( $>45$ years) and lack of sleep.

\section{Conclusion}

Work fatigue based on the fatigue assessment scale questionnaires concluded that the percentage of workers who experienced high fatigue were greater at $54.55 \%$, while respondents who experienced low fatigue fulfilled a smaller percentage of $45.45 \%$.

Suggestion from this research is to do body stretching in between about 5 minutes work time every 2 hours. Adjustment of physical and mental work capacity by reducing workload on old age workers ( $>45$ years) and setting rest periods (breaks every 2 hours of work interspersed with snacks).

\section{REFERENCES}

1. Atiqoh J, Wahyuni I, Lestyanto D. Factors Related to Work Fatigue in Convection Workers in the Tailoring Division at CV.Aneka Gunungpati Garment Semarang. J Kesmas. 2:119-126 (2014) 
2. Kusgiyanto W., Suroto, Ekawati. Relationship Analysis of Physical Workload, Work Period, Age, and Gender Against the Level of Work Fatigue in Workers Making Spring Rolls in Kranggan Village, Central Semarang District. J Kesmas 419-420 (2001)

3. Maurits, L.S. A Brief of Work Fatigue. Yogyakarta: Amara Books, pp: 27-44 (2010)

4. Rachman H. Picture of Work Fatigue in Factory Section Workers at PT. Maruki Internasional Indonesia Makassar. Universitas Islam Negeri Alauddin. Skripsi. (2013)

5. Rahmuniyati M.E, Rahfiludin Z, Kartini A. Effect of Provision of Drinking Water and Glucose Water on Hydration and Fatigue Status of Iron Pande Workers. J Formil (Forum Ilmiah) KesMas Respati. 1:69-77 (2016)

6. Setyowati, D. L., Shaluhiyah, Z. \& Widjasena, B. Causes of Work Fatigue in Furniture Workers. Kesmas: National Public Health J, 8, 386-392. (2014)

7. Sugiyono. Research methods. Bandung: CV Alfa Beta. (2001)

8. Sugiyono. Quantitative, Qualitative Research Methods, dan R\&D. Bandung: Alfabeta. (2017)

9. Suma'mur P.K. Corporate Hygiene and Occupational Health (Hiperkes). Jakarta: Sagung Seto, pp: 407-411. (2014)

10. Tarwaka. Ergonomics for Safety, Occupational Health and Productivity. Surakarta: Uniba Press, pp: 363-370. (2015)

11. International Labour Organization. Work Safety and Health Facilities Means for Productivity. ILO 5: 49. (2013)

12. WHO. Global goals for oral health 2020 (2003)

13. Yogisutanti G. Length of Sleep and Accumulation of Work Fatigue (Accumulated Fatigue) in Lecturers.. J Kesmas. 11:64. (2015)

14. Yusuf M. The Impact of Adding Work Shifts from 8 Hours / day to 12 Hours / day on Work Productivity. National Seminar on Innovation and Application of Technology in Industry. ITN Malang. pp: 1-2. (2017)

15. Sulistya W. G. Universitas Muhammadiyah Surakarta. Skripsi (2018)

16. Taufiq S.N.P.. Universitas Sebelas Maret. Tugas Akhir. (2012)

17. Peraturan Menteri Tenaga Kerja No. 5 Tahun 2018 tentang K3 Lingkungan Kerja (2018)

18. Etikariena A. Differences in Work Fatigue Based on the Meaning of Employees. J Psikogenesis.2:17(2014) 